Article

\title{
Challenges to the Promotion of Employee-Driven Innovation in State-Owned Enterprises: Two Cases from the Automotive Sector in China
}

\author{
Zhongzhen Miao and Huanyong $\mathrm{Ji}$ *(D) \\ School of Public Policy and Management, Tsinghua University, Beijing 100084, China; \\ zhongzhenmiao@mail.tsinghua.edu.cn \\ * Correspondence: jihuanyong@mail.tsinghua.edu.cn
}

Received: 4 February 2020; Accepted: 17 March 2020; Published: 19 March 2020

check for updates

\begin{abstract}
Employee-driven innovations (EDIs) are increasingly regarded as one of main source of innovation and sustainable competitive advantage, yet many studies indicate that EDIs are often undervalued in state-owned enterprises (SOEs) in China. It remains unclear what the challenges are to the promotion of EDIs in SOEs and how these challenges could be addressed with well-designed managerial practices such as a suggestion system. This study aims to address this research gap by studying two SOEs in the Chinese automotive industry using the multiple-case study method. A total of 12 respondents from the two SOEs have been interviewed as part of a four-year research project. On the basis of the analysis of two cases, it is found that SOEs that appointed a top-manager with firm-specific knowledge and long-term tenure successfully promoted EDIs with a well-designed supporting suggestion system in place. Conversely, the SOEs that appointed a top-manager with little firm-specific knowledge and short-term tenure have not successfully promoted EDIs and its suggestion system is also poorly designed. In conclusion, outsider control and short-term tenure of top manager are two major challenges to promote EDIs in SOEs. This study contributes to the literature by identifying the potential challenges of introducing EDIs and relevant practices in SOEs in China.
\end{abstract}

Keywords: employee-driven innovation; state-owned enterprises; suggestion system; corporate governance; high-involvement innovation; China's automotive industry

\section{Introduction}

Employee-driven innovations (EDIs) are increasingly regarded as one of the main sources of innovation and sustainable competitive advantage due to lessons learned from world leading firms such as Google, Apple, and Toyota [1,2]. Recently, EDIs have been found that promote eco-friendly innovations in firms, which contributes to the development of firms' sustainable competitive advantage [3,4].

Existing empirical studies related to EDIs have mainly focused on two aspects, including: (1) characteristics of employees, such as motivation from perceived well-being and interactional justice [5] and self-efficacy of employees [6] and (2) characteristics of organizations, such as leadership behavior [7], and use of team works [8]. However, these studies have been confined to investigate impact factors of EDIs at the functional level within firms, such as how certain human resource management (HRM) [9-11] and operations management (OM) [12] practices that could promote the EDIs performance. Little of them acknowledge the fact that the proposed HRM and OM practices are all heavily impacted by decision and preference of top managers of firms, to be more specific, by their perceptions towards the value of EDIs, and their willingness to allocate resources to support EDIs. 
Regardless the impact of personal characteristics and leadership style of top managers on EDIs $[7,13]$, their decision making is also heavily influenced by the firm's corporate governance, i.e., how firms are owned and controlled [14,15]. A firm's corporate governance has a significant impact on decision making of managers, and thus poses many challenges to the promotion of EDIs in firms. For instance, the characteristics of a firm's corporate governance is highly likely to impact the design and implementation of EDI-related practices that, consequently, influence the effectiveness of the EDIs [16].

Amongst many types of firm's ownership, state ownership is currently the most controversial one due to perceived poor innovation capability of state-owned enterprises (SOEs) [17]. Using China as an example, where SOEs play central roles in many strategically important sectors, it has been found that innovation activities in SOEs are often managed in a top-down fashion, thus making the implementation of bottom-up-styled EDIs particularly challenging [18-20].

As an important source of innovation, not having EDIs would certainly constrain the innovation capability of SOEs. Since SOEs in China dominate many sectors, such as energy and mining, improving their innovation capability would certainly promote the waste reduction and change of unsustainable consumption and production patterns of these sectors. Thus, it is curial to investigate how to promote EDIs in SOEs to improve their innovation capability at this stage.

Unfortunately, employees' engagement in innovation activities are commonly undervalued by managers in China's SOEs across many sectors [21,22]. There are many challenges that need to be addressed before EDIs can be successfully implemented in SOEs. However, existing the literature fails to address this topic adequately.

This study aims to address this research gap by addressing the following research questions:

RQ1 What are the challenges to promote EDIs in China's SOEs from corporate governance perspective?

RQ2 How to address these challenges with appropriately designed practices?

By addressing research questions, this study aims to identify challenges to the promotion of EDIs in SOEs from a corporate governance perspective and showcase some appropriately designed managerial practices that could address these challenges.

This study employs a multiple-case research design [23] that aims to develop an in-depth understanding of how the challenges, as discussed above, could be addressed. Two representative cases are selected from the Chinese automotive sector. Top managers and middle managers in the two SOEs were interviewed between August 2015 and February 2016 as part of a four-year research project. Due to a confidentiality agreement made during the project, in this study, their names are replaced by Case A and B to protect their interests.

Section 2 of this paper includes a discussion of relevant literature on EDIs and how corporate governance could pose challenges to promote EDIs in SOEs. Section 3 includes a discussion of the research methodology used to collect and analyses data. Section 4 outlines the analysis of cases. Section 5 provides the findings in relation to the existing literature. Section 6 presents conclusions and makes suggestions for future research.

\section{Related Work}

In order to address the research questions, relevant studies in the field of EDIs and the connection to SOEs are reviewed to identify potential challenges to the promotion of EDIs in SOEs. Additionally, literature focused on the impact of corporate governance on innovation has also been discussed to provide theoretical support to the identification of challenges.

\subsection{Employee-Driven Innovations}

The notion of EDIs originated from the theory of continuous improvement (CI) and high-involvement innovation (HII) that have been widely applied in firms in Japan and Scandinavia countries $[24,25]$. The concept of EDIs emphasizes the engagement of "ordinary workers", who are 
not managers or R\&D personnel in innovation activities [26,27]. Employees possess valuable tacit knowledge accumulated at the workplace such as working experiences and in-depth understanding of routines [28]. In a firm where EDIs are well accepted and supported, all employees are encouraged to develop, process, and even product innovations, sometimes outside of their job design [16,29].

Recently, the EDIs have been found that promote eco-friendly innovations in firms [3,4]. Eco-friendly innovations are one of major concerns in the manufacturing sector nowadays, which are widely viewed as the main driver of firms environmental performance and sustainable competitive advantage [4,30-33]. Therefore, in the era of environmental protection and energy conservation, promoting EDIs in firms are both economically and socially valuable initiatives.

The role of employees in the innovation process has been widely acknowledged and studied from various angles. Human resource management (HRM) studies on this topic stress the development of employee competence through trainings, empowering employees, involving them into decision making and innovation process, and consequently improving firms innovation performance [9-11]. Knowledge management and organizational learning literatures focus on sharing and using tacit knowledge possessed by ordinary employees through collective learning [34-36]. Lean management research in this field emphasizes the central role played by employees in CI and contribution to firm's innovations and sustainable competitive advantage [12,24,25]. CI encourages employees to learn from daily trial and error in order to develop innovation in a problem-solving fashion $[37,38]$. The valuable working experiences and in-depth understanding of daily routines are critical sources of creative ideas, which managerial and R\&D personals often do not have [28].

To promote the implementation of EDIs in firms, supportive management practices are required [11,39], for instance, a suggestion system is one of the most commonly used practices that promotes EDIs $[5,6]$. Some recent studies are starting to notice the importance of top managers support to successful EDI implementations [40], especially their willingness to allocate resources to support and motivate employees to engage in innovation [39,41,42]. Several empirical studies have found a positive relationship between the resources allocated to EDIs and the employees' engagement in the innovation activities $[3,7]$.

However, these studies seem to take managers' willingness to support EDIs for granted, which is clearly not the case in reality. Regardless of the personal characteristics of top managers $[7,13]$, their decisions are made under many constrains from the corporate governance point of view, for instance, top managers in the large firms in the UK are often under short-term pressures from their shareholders, like pension funds and insurance companies, and therefore they cannot afford to invest in innovation projects that have long payback period, like in-house R\&D [14].

Therefore, some top managers choose to not adopt EDIs in their firms. Although in firms that have adopted EDIs, it has been found that the firms' design and use of their suggestion systems are different, and therefore the system does not work in some firms [40,43]. Top managers' decision making is a key determinant to a firm's adoption of innovative management practices [44], thus, whether the suggestion system works or not is highly influenced by characteristics of managers in top positions.

The existing literature acknowledges the phenomenon that managerial practices that support EDIs may not work owing to poor design of those practices by managers. However, these studies fail to note the managers' disregard of EDIs could be rooted in challenges at the corporate governance level. According to several studies on China's SOEs, top managers in those SOEs tend to undervalue innovative efforts at the shop floor due to the way those SOEs are owned and controlled [45-47], and thus are unlikely to pay much attention to designing an effective suggestion system that promotes EDIs. Given this, the challenges to the promotion of innovation capability development and EDIs in SOEs are discussed in the following section from the corporate governance perspective.

\subsection{Innovation Capability Development and Corporate Governance of China's SOEs}

Since the late 1990s, increasing attention has been given to investigating the impact of corporate governance on the development of innovation capability and sustainable competitiveness $[15,48,49]$. 
This group of studies is rather broad in terms of the sectors studied, including the automotive sector [22], the telecommunication sector [45], the heavy machinery sector, and the television sector [46].

It has been found that the supervision and management infrastructures of SOEs cause a major flaw in the process of innovation capability development $[45,50]$. A key weakness of China's SOEs that has been identified is the management appointment of top managers to SOEs by the SASAC (State-owned Assets Supervision and Administration Commission) [46,51]. Because the top managers of SOEs are usually officials from government agencies, they lack relevant professional knowledge to closely monitor the SOE [22]. In addition, because these top managers are likely to leave the SOEs in the short-term of around five years, they do not have responsibility for the long-term development of the SOEs [47]. Consequently, these top managers become disengaged with the SOE because their career development and personal gains are not closely linked with the long-term development of the SOEs [21].

The disengaged top managers in China's SOEs are also reluctant to invest in long-term and innovation capability development activities, such as the training of employees [17,52]. At the same time, the management of the firm is very exclusive, which does not involve the participation of ordinary employees in the process of decision making and innovation [22]. This problem leads to major losses of knowledge embedded in employees, and causes weaknesses in problem solving, as well as the development of innovation capability [52]. Therefore, promoting EDIs is very difficult in these SOEs due to the lack of management support and involvement of employees in the process of innovation.

From several cases of China's SOEs, it has been found that some of the SOEs tend to purchase readymade, fully assembled, and packaged technologies and equipment (e.g., entire production lines) because these technological bundles can boost firm performance in the short-run, and therefore observable outcomes can be produced during their four- to five-year term in office [45]. The drawback of using bundled technology is that engineers do not understand the underlying principle of how and why each part of the bundle works together as a production system, consequently, engineers are not able to modify or improve them [52]. This is because the relevant technological knowledge (knowledge about how things work together) is usually accumulated gradually in the process of developing the technology, and is often tacit and embodied in the employees who were part of the development process [53]. Therefore, if a top manager of a SOE is appointed for a short-term tenure only, the manager is unlikely to appreciate the innovation and capability developing activities of ordinary employees.

To sum up, corporate governance of SOEs have a significant impact on its innovation capability development, especially the part that requires the involvement of employees in problem solving and collectively learning. On the basis of the discussion above, it is reasonable to anticipate that the promotion of EDIs is highly likely to be very difficult if a SOE has been appointed a top manager who does not have sufficient knowledge of the industry and firm and is likely to leave in four to five years.

\subsection{Potential Chanllange to EDIs in SOEs from the Corporate Governance Pespective}

Although China has transformed itself to a more marketized economy since the late 1980s, the central and local governments are still strongly intervening in the economy because they still own a high number of large companies in mid-tech, mid-high-tech, and high-tech industries [54]. SOEs in China dominate most of important sectors which the Chinese government have classified into two main groups, namely the "Strategic and Key Industries" and the "Basic and Pillar Industries" [47] (p. 343). Both groups of industries are considered as crucial to China's market stability, economic growth, and national security [55]. Therefore, it is valuable to study EDIs in the context of SOEs aiming to improve innovative capability of SOEs, given their vital role to the economy in China.

As discussed above, the appointment of top manager is one of the major problems in the corporate governance of China's SOEs, which has a profound impact on the innovation capability development in SOEs. In addition, it seems that the top manager's level of firm-specific knowledge and their length of tenure are two major influencing factors to the involvement of employees in the process of innovation. On the basis of the discussion above, we propose the following two potential challenges to 
the promotion of EDIs in China's SOEs from the corporate governance perspective: First, outsider control of firms and second, short-term tenure of top managers. They are briefly discussed below.

\subsubsection{Outsider Control of a Firm}

The outsider control of a firm is a challenge to EDIs, as top managers tend to undervalue EDIs due to not having sufficient firm-specific expertise, and therefore they are not capable of understanding the value of low-visibility innovation efforts at the shop floor [49,50].

Whether firms are controlled by top managers who have enough firm-specific knowledge is a crucial factor that has profound impacts on the innovation management of firms. Top managers need to be able to appreciate innovation activities that are difficult for them to recognize at a distance, especially when top managers are "outsiders" who lack the industrial and firm-specific knowledge to know how technologies and other systems work in the firm $[49,56]$. This also requires top managers to engage in daily operations of firms to understand why certain slow, and less visible innovation efforts, are necessary for developing technological innovations in their sector [21,57].

\subsubsection{Short-Term Tenure of Top Managers}

The short-term tenure of a top manager is a challenge to EDIs due to the lack of support from top managers who are frequently reassigned by the government [52]. Top managers need to be motivated and rewarded in ways that allow them to secure greater gains from the long-term development of the firm because innovation requires patient investment. Otherwise, short-termism gain has a harmful impact on the development of innovation capability of the firm in the long-run [58].

If top managers have long tuners in firms, they have a higher stake in the successful long-term performance of the firm. Thus, they are more likely to plan for the long-term development of innovation capability and allow for patient investment on such slow-payoff innovation efforts, which consequently results in sustainable competitive advantage [59]. Additionally, appointments for long-term employment also reduce the "short-term pressure" on top managers, and therefore they are able to be patient with slow returns from investment in innovation activities [60] (p. 7), such as EDIs.

\section{Materials and Methods}

This research chose to use multiple-case study research to analyze research questions according to prior studies [23]. The case study method is great for studying topics that have not been extensively explored before. Yin [23] (p. 18) defines the case study method as "an empirical inquiry that investigates a contemporary phenomenon within its real-life context, especially when the boundaries between phenomenon and context are not clearly evident." In the context of this study, the first research question aims to identify some challenges to promote EDIs in China's SOEs from the corporate governance perspective in order to raise the awareness of this problem among scholars and industrial practitioners. The difficulty of promoting EDIs in SOEs is a contemporary phenomenon in real-life, overlooked in existing literatures, and thus requiring exploratory study to address this research gap. The second research question is to investigate how the identified challenges could be solved by appropriately designed management practices so that some insights about good practices in promoting EDIs in SOEs could be produced.

Theoretical sampling is used in this study as it helps identify patterns and relationships between constructs when purposely selecting cases with possible contrasting outcomes [61]. Therefore, in this study, we select two SOEs from the same sector but having different innovation performances in order to compare two cases at the data analysis stage.

\subsection{Case Selection}

After selecting from several available cases, two cases were selected as follows: One is an example of a poorly performing SOEs and another is an example of a good performing SOEs, in China [62]. They have very similar background in terms of sector and the form of ownership making them 
comparable in this study. Case A is a traditional SOE that has poor innovation performance, thus, EDIs are expected to be poorly promoted, in this firm. By studying Case A, some challenges to EDIs in SOEs could be identified and analyzed. Conversely, Case B is a market leader who is also a SOE but has good innovation performance, and thus are expected to have effective practices promoting EDIs. This case is selected to contrast with Case A aiming to produce lessons about how challenges to EDIs could be managed from a successful case. In total, two contrasting SOEs in China's automotive sector that have different innovation performances are selected to address research questions in this study.

Although the case study method is appropriate to address research questions in this study, the authors acknowledge the limitations of using this method. First, this study does not intent to produce results that are widely generalizable in other contexts. This study aims to only shed light on a real-life contemporary phenomenon by sharing some insights produced by studying two representative cases. Secondly, this study does not aim to identify all the possible challenges to the promotion of EDIs in SOEs, since only two cases has been studied. However, as an early attempt to investigate the problem starting with two cases, this study raises the awareness of this problem and lays the first block for following research to build upon. Third, this study does not plan to claim causal relationship between challenges identified and the success in promotion of EDIs in the SOEs studied. However, based on the discussion of existing literature and the logical analysis of case data, we propose a correlation between challenges identified and the success in promotion of EDIs. Such a correlation could be later confirmed as a causal relationship in another quantitative study, but this is out of the scope of this study.

\subsection{Data Collection and Triangulation}

Twelve in-depth semi-structured interviews were conducted between late 2015 and early 2016 as a part of a four-year research project. Twelve respondents were mainly high and mid-level managers in charge of R\&D, quality management, and HRM, as well as some ordinary employees (see Appendix A for a summary of respondents). High-level managers were interviewed because they are responsible for making decisions on the design and use of managerial practices to support EDIs. Mid-level managers were interviewed because they would have more experience with the operation EDIs related practices.

Interviews with ordinary employees are very difficult in the Chinese context, especially in SOEs as they are often very bureaucratic. In our previous projects, many low-level employees have been given specific transcripts by their supervisor during the interviews so that employees cannot express their own opinions. Interview employees of SOEs covertly bypassing their managers could potentially cause harm to the personal interests of employees, and even jeopardizing their career. Therefore, in consideration of research ethics, ordinary employees were only interviewed when granted permission by their managers. Because of the limited access to ordinary employees, their responds are mainly used to verify and supplement the information provided by managers.

Although ordinary employees were not widely interviewed in this research, information provided by mangers was sufficient for identifying challenges to the promotion of EDIs in their firms, and to understand how appropriate management practices are designed to support the EDIs in their firm.

Interview guidance was provided to interviewees a week prior to the interviews to allow interviewees to gather necessary information for answering questions. Each interview last between 1 and 1.5 hours. All interview transcripts were translated by the researchers. Translation were double checked by multilinguistic members of faculty and international students.

Yin [23] (p. 116) proposed using "triangulation" as a method to verify findings from case studies by collecting data from multiple sources. This research triangulates the research results in three main ways.

First, this research interviewed multiple respondents in each case to eliminate bias in the interview data [63]. Multiple interviewees were interviewed in each of the firms studied which allowed the researcher to compare the information provided by one interviewee with what was provided by others. Only the information that was not in conflict with what was provided by other interviewees was used for further data analysis, and the generation of findings. 
Second, the researcher asked questions on the detailed implementation of EDI-related practices to avoid false information being given by interviewees. For example, when asking whether a firm has adopted a working suggestion system, questions were selected to ask very specific details including, which part of the workforce was involved in this system; how suggestions were collected from the shop floor workers; how often could employees proposed suggestions; what types of suggestion were expected from workers; who was responsible for assessing the usefulness of the suggestions; what was the background of the people who assessed the suggestions; how were good suggestions rewarded, and so on. These detailed questions allowed the researcher to know whether interviewees were telling the truth about what was really happening, or if they simply wanted to look good in public.

Lastly, data from different sources was used in this research [64]. The researcher collected a significant amount of secondary data from online news, the company's website, annual reports, documentaries, archives, and so on (for a list of secondary data collected, please refer to Table 1). Moreover, the firm's internal documentation such as internal reports, internal newspapers, etc. were also acquired when permitted. These secondary data were selected as they contain information that helps the researcher to understand the history of the company in question, to explore how EDI related practices are implemented in the firm, and to validate the information provided by the interviewees. Thus, these data play a crucial role in the process of data analysis, especially in addressing research question two (RQ2) by providing details on the design and operation of managerial practices.

Table 1. List of secondary data collected.

\begin{tabular}{cccc}
\hline \multirow{2}{*}{ Cases } & Type of Secondary Data & Amount & $\begin{array}{c}\text { Usage in data analysis } \\
\text { (Validating/Complementing } \\
\text { Interview Data) }\end{array}$ \\
\hline \multirow{2}{*}{ Case A } & Online news & 42 & Validating \\
\cline { 2 - 4 } & Internal reports & 11 & Validating and complementing \\
\cline { 2 - 4 } & Internal newspaper & 12 & Validating \\
\cline { 2 - 4 } & Archive & 1 & Validating \\
\cline { 2 - 4 } Case B & Online news & 89 & Validating \\
\cline { 2 - 4 } & Internal reports & 52 & Validating and complementing \\
\cline { 2 - 4 } & Internal newspaper & 24 & Validating \\
\cline { 2 - 4 } & Internal book & 1 & Validating \\
\cline { 2 - 4 } & Documentary & 2 & Validating \\
\cline { 2 - 4 } & Archive & 6 & Validating \\
\hline
\end{tabular}

\section{Case Analysis}

In this section, data collected from the two contrasting cases selected from China's automotive sector are analyzed. At the beginning of each case analysis, a brief introduction of the case is provided. Then, the challenge of outsider control and short-term tenure of top managers are analyzed, followed by a detailed study of a firm's design and operation of suggestion system. It is worthwhile to note that the top manager in this study refers to the chairman of the board of shareholders who oversees the daily operation of SOEs.

\subsection{Case $A$}

Case A is a large diesel engine manufacturer based in Northern China, founded in the 1950s, supplying mainly to manufacturers of heavy-duty special vehicles and mobile emergency generators in the domestic market. It has about 5000 employees. Case A is a full subsidiary of a large SOE group fully owned by the state-owned assets supervision and administration commission (SASAC). 
Case $\mathrm{A}$ is at the transformational stage between its former and present chairman at the time of interviews, in early 2016. The new chairman was appointed directly by the SASAC from outside, so he had never worked in Case A or the parent company before. The VP of Case A stated that: "... our new Chairman was a secretary of the governor of a province. He has not worked in this (automotive) sector before.... he is a total layman (person not knowing the technology) selected by our parent company or even by central SASAC directly from outside of our system (central SOEs in automotive sector) ... (A-VP)". Therefore, because the new Chairman had never worked in this SOE, he was considered as an outsider who did not have sufficient firm-specific knowledge. Thus, he was not expected to appreciate EDIs.

As mentioned above, the current top manager of Case A had just been appointed by the parent company on behalf of the SASAC in early 2016. Thus, he had only worked in Case A for one year. It is unclear whether he would stay with long-term tenure or not as it is solely up to the plans of the SASAC. However, based on the experience from their former chairman, who had only worked for five years, the tenure of the current Chairman was unlikely to be long. Therefore, the level of incentive of the chairman in Case A to promote EDIs was likely to be low.

In Case A, the firm had implemented a suggestion system labelled Suggestion Scheme aiming to collect suggestions from employees since 2012 (see Appendix B for the structure of this suggestion system). As a SOE, their initiative to adopt the suggestion system derived from the instruction issued by the SASAC.

The Suggestion Scheme of Case A was an event-like program which ran once a year lasting around a month. It was managed by mid-level managers at the department level. Mid-managers collected suggestions from employees in their departments once a year and selected good suggestions to report to the high-level managers.

Employees participated in the Suggestion Scheme on a voluntary basis. Each suggestion was rewarded with $5 \mathrm{RMB}$. At the end of the Suggestion Scheme every year, the top five suggestions were selected by high-level management and given financial rewards. The financial reward for the top five suggestions varied every year, but on average it was approximately 800 RMB.

However, the suggestion system in Case A was not very effective in promoting EDIs. According to the interviewees, the suggestion system in Case A lacked management support. Lack of management support made low-level employees fear that offering suggestions to higher level managers would upset their direct supervisors and lead to some form of punishment. One CNC worker reports that: "I normally just report it [suggestions] to my master because it is a terrible thing to report something to higher level management without telling your direct superiors. ... This will make my superiors unhappy, so will make me miserable later on ... (A-CNC)". This indicates that the high-level managers do not show strong support to employees who propose suggestions directly to them. In addition, the responses from this interviewee indicate that proposing suggestions that bypass their direct supervisor is deemed unacceptable in Case A. In addition, the suggestion system was only open once a year, which is unlikely to make a real impact on EDIs.

From the analysis of Case A, it is evident that the firm is controlled by an outsider with perceived short-term tenure. In addition, from the details of the suggestion system employed in the Case A, EDIs are unlikely to be supported by such a system. Therefore, the two potential challenges identified in literature are confirmed in the case A.

\subsection{Case B}

Case B is a large commercial vehicle manufacturer based in Beijing founded in 1996. It has nearly 40,000 employees in subsidiaries located across nine provinces in China. This firm is majority-owned by Beijing SASAC. It is specialized in producing medium and heavy-duty trucks, vans, special vehicles, and renewable energy commercial vehicles running on Li-ion batteries.

The current chairman of Case B has been in this position since 2002 and was appointed directly by the Beijing SASAC. So, he has worked in the same company and same position for nearly 15 years. 
This is a considerably long tenure for a top manager in China's SOEs as compared with the traditional tenure of four to five years noted in the literature [22].

At the time he was appointed, he did not have any formal education within the automotive industry. However, before he was appointed as the chairman, he had worked very closely with Case B during his previous job as a government official who was responsible for developing industrial policies for the local automotive industry. It was noted by a vice president (VP) of Case B that "... His job was a government official in our local government who was responsible for developing local industrial policies.... He worked intensively with our company to develop competitiveness of the local automotive industry ... planned strategically by local government.... Since our parent company is the only SOE [large corporate group] in the local automotive sector, he worked closely with our company to work out ways to improve production capability and product quality [of commercial vehicles].... He was acting as a bridge connecting our company with the local government to apply for necessary capital ... (B-VP)".

Therefore, the chairman of Case B is considered as having in-depth, firm-specific knowledge. This was because the current chairman had opportunities to develop some firm-specific knowledge before being appointed. Furthermore, the current Chairman had nearly 15 years of work experience in Case $B$ at the time of being interviewed. Therefore, he was expected to understand and appreciate low-visibility innovation activities at the shop floor such as EDIs.

The suggestion system of Case B was introduced around 2010 as part of the introduction of the Toyota Production System (TPS) (see Appendix C for the structure of this suggestion system). They invested nearly 1 million RMB in hiring a professional management consulting company from Japan to design the TPS for them. To manage the suggestion systems in Case B, they established a Product Creation Committee at the company level that was specifically responsible for collecting, evaluating, and implementing suggestions made by employees. This committee was comprised of permanent members of staff including the CEO, vice presidents, and senior level engineers, along with temporary staff members including technological experts from different departments, and experts from universities and other external organizations. Therefore, such a committee had both firm-specific and industry-specific expertise when evaluating suggestions from employees.

Their suggestion system had two main parts, namely the Kaizen Idea Programme and the Kaizen Team Programme, both managed by a Product Creation Committee at the company level.

The first part was called the Kaizen Idea Programme which collected work-related suggestions from all employees aiming to improve work efficiency by making incremental changes to the work processes.

The system was designed to allow employee participation in the system on a voluntary basis. However, the involvement of employees in this program was very low because of a lack of a company-wide culture to encourage proposing suggestions to higher level managers, which was a similar problem to the one faced by Case A.

Thus, in 2011, Case B changed the system to become a compulsory program that all employees, including managers, must propose a certain number of work-related suggestions to the Kaizen Idea Programme every year. This program ran throughout the year so that employees could make their suggestions at any time. According to the VP “... everyone was asked to make five suggestions related to their job.... Those suggestions will be proposed directly to our committee [Product Creation Committee] through our online system so that other managers cannot manipulate their subordinates in this [suggestion making]." (A-VP)

Therefore, with a compulsory suggestion system, the involvement of employees in making suggestions has improved dramatically. However, a compulsory system cannot guarantee the quality of suggestions made by employees. Thus, Case B introduced an incentive mechanism to reward good suggestions with greater financial rewards. High quality practical suggestions were selected by the Product Creation Committee every year, and awards varying from 2000 to 5000 RMB were given to each good suggestion. The average salary of a shop floor worker in Case B was around 4000 RMB. Thus, the amount of financial reward was high enough to motivate employees to make high-quality suggestions. 
It was noted by the Head of Production department that "the quality of suggestion (Kaizen Idea) and projects (Kaizen Teams) has improved dramatically in last few years. I think it is because we have gradually developed a culture in our company that encourages them [the shop floor workers] to make suggestions and improve their work.... I feel that proposing ideas to managers is very common among our workers now." (B-HoP)

The second part was the Kaizen Team Programme, which allowed employees to form small project teams on a voluntary basis to solve any complex technological problems they choose. The Kaizen teams needed to first register their projects with the Product Creation Committee. After the committee had approved their projects, they were able to apply for resources and working hours to work on their projects. If the project successfully solved challenging technological problems, the company rewarded them financially. The amount of reward ranged from 5000 to 20,000 RMB to each team member. Furthermore, Case B allowed the Kaizen teams to patent their outcomes privately. Then, the company would purchase the patents from the employees at market value. This mechanism allowed employees to be well compensated if they develop innovative solutions to challenging technological problems.

From the analysis of Case B, it is evident that the firm does not have the issue of outsider control and short-term tenure of top managers. In addition, from the operational detail of their suggestion system, it is easy to conclude that EDIs are well supported by such a system in the Case B.

\section{Findings and Discussions}

From the analysis of two contrasting cases, the following two challenges to the promotion of EDIs in SOEs from the corporate governance perspective have been identified: First, the outsider control of the firm and, second, the short-term tenure of top managers. The top manager of Case A was appointed from outside of the SOEs and had no expertise in automotive technologies before, and therefore was unlikely to appreciate EDIs in the development of the firm's innovation capability. In addition, because the top manager had been appointed with a short-term tenure around four to five years, he was not expected to plan for the long-term development of the firm. Therefore, very limited resources were allocated to reward employees after they had submitted suggestions to the suggestion system in Case A. These findings are in line with the existing literature on SOEs in China $[46,47,50]$ that outsider top managers tend to undervalue low-visibility innovation activities at the shop floor.

In addition, submitting suggestions bypassing direct supervisors was considered as inappropriate in the Case A's culture, thus employees were reluctant to propose suggestions. This phenomenon has been noted by Child [65], who suggested that mid-level managers consider being bypassed as undermining their management authority. Given this, the EDI is highly unlikely to be successfully promoted in Case A, thus, unable to contribute to the development of the firm's innovation capability.

Interestingly, although Case B is also a SOEs, it has managed to take full advantage of EDIs in developing their innovation capability. From the analysis of Case B, it was found that the top-manager of the firm had rich firm-specific knowledge as he had worked as the chairman of the same SOEs for over 15 years. In addition, he had worked closely with Case B when he was a government official who managed industrial policy for automotive industry in the local government. Therefore, very different from what has been proposed in the existing literature [46,47,50], Case A had appointed an insider as the top manager with long-term tenure. This finding suggests that not all of China's SOEs are managed in the same way form the corporate governance point of view, which the existing literature has so far failed to acknowledge.

From the operational details of Case B's suggestion system, it is evident to observe that Case B has invested heavily in the design and operation of this system. One of distinctive feature of Case B's suggestion system is that it allows employees to patent their innovation and sell it back to Case $\mathrm{B}$ at market price. This would cost Case B a great fortune when motivating employees to engage in innovation activities.

Case B had a similar problem to Case A in that employees were unwilling to submit suggestions at the beginning. Thus, Case B changed its suggestion system from a voluntary one to a compulsory 
one which required all employees (including managers) to submit a certain number of suggestions annually. By doing this, the issue of employee's disengagement to the suggestion system has been solved. Moreover, a culture that encourages proposing and accepting suggestions has been built. Consequently, submitting suggestions bypassing direct supervisors are no longer an inappropriate action in Case B.

Form the analysis of Case B, it shows that the challenges to EDIs in SOEs have been successfully addressed by appointing a top manager with firm-specific knowledge for a long-term tenure. In this way, EDIs can be effectively promoted in the SOE and contribute to the firm's development of innovation capability. Additionally, EDIs can still be successfully promoted in SOEs that have an outsider as the top manager who has short-term tenures, such as the lessons learned from Case B, in which a well-designed and heavily-rewarded suggestion system could greatly promote the EDIs.

\section{Conclusions}

This study aimed to study the challenges of promoting EDIs in SOEs from the corporate governance perspective, and how these challenges could be addressed with well-designed managerial practices that support EDIs. By reviewing literature and empirically verify propositions based on multiple-case studies, two challenges have been identified which include (1) the outsider control of SOEs and (2) the short-term tenure of top managers in SOEs. By studying two contrasting cases selected from the Chinese automotive industry, several good practices have been found to address these two challenges, and to facilitate EDIs using well-designed suggestion systems.

On the basis of the results from two cases studied, we found that the SOE that had been appointed an outsider as the top manager did not have successfully promoted EDIs. Conversely, the SOE that had an insider as the top manager had successfully promoted EDIs. Moreover, the SOE that had top managers with short-term tenure did not have successfully promoted EDIs. On the contrary, the SOE that had top managers with long-term tenure had successfully promoted EDIs. By successfully promoted EDIs, it refers to EDIs that are well supported in SOEs, and thus can contribute to the development of innovation and the sustainable competitive advantage of firms.

This study contributes to our knowledge by identifying two challenges to the promotion of EDIs in SOEs from the corporate governance perspective base on studying two cases selected from China's automotive sector. In addition, we found that SOEs in China are not managed in the same way by the SASAC. Some SOEs appoint industrial experts as top managers for long-term tenures.

In terms of practical contributions, several good practices for designing working suggestion systems have been found from the case analysis such as allowing employees to patent their innovation and sell it back to their firm, and making the suggestion system a compulsory one at the beginning to build the culture first. These findings could provide insights to academics in the field of EDI studies, and to industrial practitioners who intended to also promote EDIs.

Although this research has successfully addressed the research questions, this research has several limitations. Therefore, several recommendations for future research are proposed below.

First, this research has only studied two SOEs in China's automotive sector, therefore, it could only provide some insights on the challenges to the promotion of EDIs in SOEs and how these challenges could be addressed with managerial practices. As suggested in the earlier literature [66-69], the foundation of innovation is interactive learning and creative problem solving amongst employees. Thus, EDIs could certainly play a critical role in other sectors, particularly in other engineering sectors that rely on a similar knowledge base to the automotive industry.

Future research could study challenges to promote EDIs in SOEs in other engineering sectors. Especially, attention should be paid to mid-high-tech sectors as they rely on both formal R\&D and EDIs to develop innovation capability.

Second, as mentioned in Section 3.1, this research uses the multiple-case study method, and thus we are unable to produce conclusions that are widely generalizable in other contexts. Therefore, 
quantitative studies are recommended in future research to investigate the casual relationship between challenges and EDIs in SOEs.

Third, we only studied SOEs in China where SOEs are still playing dominant roles in some industries. The lessons learned from this research could also provide some insights to other countries where the SOEs also plays a significant role in the market. The management of SOEs by the state is not necessarily the same across other countries. Therefore, future research that studies EDIs in SOEs in other countries would be particularly welcomed.

Lastly, as discussed in Section 3.2, the authors had limited access to interview employees. Since this study aimed to study the EDI from the corporate governance perspective, information provided by managers was sufficient and appropriate to address the research questions. However, this study is merely an early attempt to identify some of the challenges to the promotion of EDIs in SOEs, and to motivate future studies around this topic. Using data collected from ordinary employees would be particularly encouraged in future research and would be more likely to produce operationalizable insights to help industrial practitioners address the challenges.

Author Contributions: Conceptualization, Z.M.; methodology, Z.M.; validation, H.J. and Z.M.; formal analysis, Z.M.; investigation, Z.M. and H.J.; data curation, Z.M. and H.J.; writing-original draft preparation, Z.M.; supervision, H.J.; project administration, Z.M.; funding acquisition, Z.M., H.J. All authors have read and agreed to the published version of the manuscript.

Funding: This research is supported by the National Natural Science Foundation of China $(71974107,91646102$, L1824039, L1724034, L1624045, L1524015), the MOE (Ministry of Education in China) Project of Humanities and Social Sciences (Engineering and Technology Talent Cultivation) (16JDGC011).

Conflicts of Interest: The authors declare no conflict of interest.

\section{Appendix A}

Table A1. Summary of respondent and coding cited in the main text.

\begin{tabular}{|c|c|c|c|c|}
\hline Interview Number & Company & $\begin{array}{c}\text { Level of } \\
\text { Interviewees }\end{array}$ & Position & $\begin{array}{l}\text { Interviewee Code } \\
\text { Cited in Text }\end{array}$ \\
\hline 1 & \multirow{8}{*}{ A } & \multirow{3}{*}{ High } & Member of board of shareholder & A-BM \\
\hline 2 & & & Vice president & A-VP \\
\hline 3 & & & Chief engineer & A-CE \\
\hline 4 & & \multirow[t]{2}{*}{ Mid } & $\begin{array}{l}\text { Head of New product } \\
\text { development Depart. }\end{array}$ & A-HoNPD \\
\hline 5 & & & $\begin{array}{l}\text { Deputy Head of New product } \\
\text { development Depart. }\end{array}$ & A-DHoNPD \\
\hline 6 & & \multirow{3}{*}{ Employee } & CNC operative & $\mathrm{A}-\mathrm{CNC}$ \\
\hline 7 & & & Low level engineer & A-LLE \\
\hline 8 & & & Quality control personnel & $\mathrm{A}-\mathrm{QC}$ \\
\hline 9 & \multirow{4}{*}{ B } & \multirow{3}{*}{ High } & Member of board of shareholder & B-BM \\
\hline 10 & & & Vice president & B-VP \\
\hline 11 & & & Chief engineer & B-CE \\
\hline 12 & & Mid & Head of production Depart. & B-HoP \\
\hline
\end{tabular}




\section{Appendix B}

Normal reporting line

Suggestion System

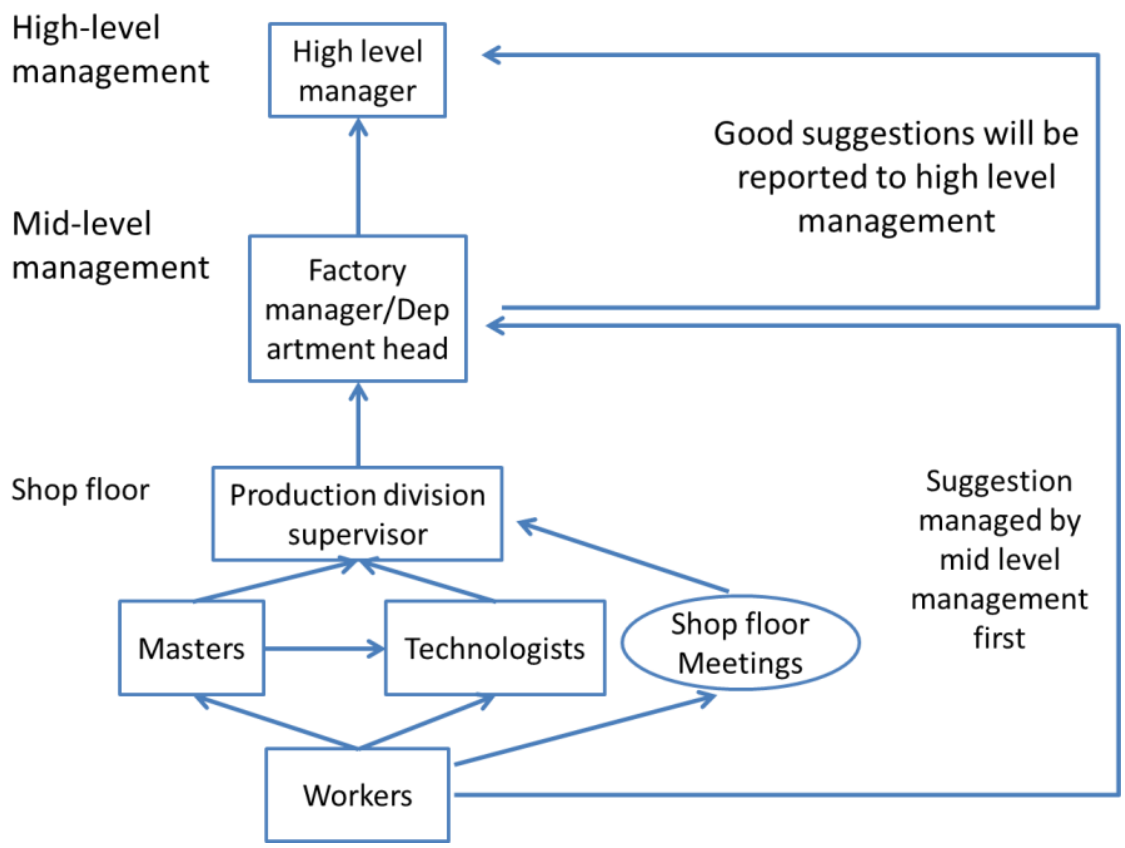

Figure A1. Structure of the suggestion system in Case A.

\section{Appendix C}

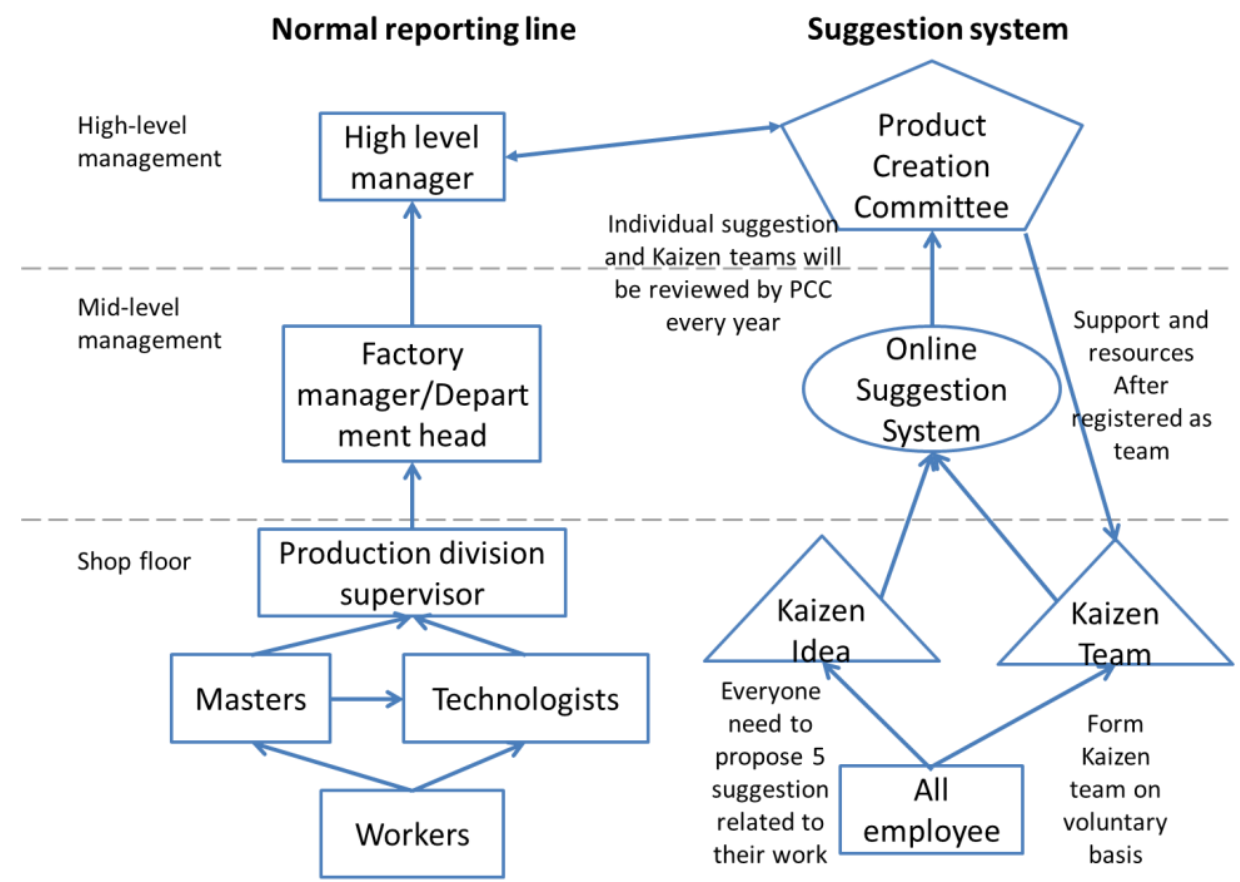

Figure A2. Structure of the suggestion system in Case B.

\section{References}

1. Hansen, K.; Amundsen, O.; Aasen, T.M.; Gressgård, L.J. Management practices for promoting employee-driven innovation. In Workplace Innovation; Springer: Berlin/Heidelberg, Germany, 2017; pp. 321-338. 
2. Pandher, G.S.; Mutlu, G.; Samnani, A.K. Employee-based innovation in organizations: Overcoming strategic risks from opportunism and governance. Strat. Entrep. J. 2017, 11, 464-482. [CrossRef]

3. Buhl, A.; Blazejewski, S.; Dittmer, F. The more, the merrier: Why and how employee-driven eco-innovation enhances environmental and competitive advantage. Sustainability 2016, 8, 946. [CrossRef]

4. Weigt-Rohrbeck, J.; Linneberg, M.S. Democratizing innovation processes: Personal initiative in bottom-up eco-innovation. Eur. J. Innov. Manag. 2019, 22, 821-844. [CrossRef]

5. Buech, V.I.; Michel, A.; Sonntag, K. Suggestion systems in organizations: What motivates employees to submit suggestions? Eur. J. Innov. Manag. 2010, 13, 507-525. [CrossRef]

6. Frese, M.; Teng, E.; Wijnen, C.J. Helping to improve suggestion systems: Predictors of making suggestions in companies. J. Organ. Behav. 1999, 20, 1139-1155. [CrossRef]

7. De Jong, J.P.; den Hartog, D.N. How leaders influence employees' innovative behaviour. Eur. J. Innov. Manag. 2007, 10, 41-64. [CrossRef]

8. Arundel, A.; Lorenz, E.; Lundvall, B.Å.; Valeyre, A. How Europe's economies learn: A comparison of work organization and innovation mode for the EU-15. Ind. Corp. Chang. 2007, 16, 1175-1210. [CrossRef]

9. Doeringer, P.B.; Lorenz, E.; Terkla, D.G. The adoption and diffusion of high-performance management: Lessons from Japanese multinationals in the West. Camb. J. Econ. 2003, 27, 265-286. [CrossRef]

10. Luoh, H.-F.; Tsaur, S.-H.; Tang, Y.-Y. Empowering employees: Job standardization and innovative behavior. Int. J. Contemp. Hosp. Manag. 2014, 26, 1100-1117. [CrossRef]

11. Lee, Y.-N.; Walsh, J.P. Inventing while you work: Knowledge, non-R\&D learning and innovation. Res. Policy 2016, 45, 345-359.

12. Lewis, M.A. Lean production and sustainable competitive advantage. Int. J. Oper. Prod. Manag. 2000, 20, 959-978. [CrossRef]

13. Opoku, M.A.; Choi, S.B.; Kang, S.-W. Servant leadership and innovative behaviour: An empirical analysis of ghana's manufacturing sector. Sustainability 2019, 11, 6273. [CrossRef]

14. Tylecote, A.; Ramirez, P. Corporate governance and innovation: The UK compared with the US and 'insider'economies. Res. Policy 2006, 35, 160-180. [CrossRef]

15. Tylecote, A.; Conesa, E. Corporate governance, innovation systems and industrial performance. Ind. Innov. 1999, 6, 25-50. [CrossRef]

16. Holman, D.; Totterdell, P.; Axtell, C.; Stride, C.; Port, R.; Svensson, R.; Zibarras, L. Job design and the employee innovation process: The mediating role of learning strategies. J. Bus. Psychol. 2012, 27, 177-191. [CrossRef]

17. Cai, J.; Tylecote, A. A healthy hybrid: The technological dynamism of minority-state-owned firms in China. Technol. Anal. Strateg. Manag. 2005, 17, 257-277.

18. Liu, X.; Lundin, N. Toward a Market-Based Open Innovation System of China; Graduate University of Chinese Academy of Science: Beijing, China, 2007.

19. Motohashi, K.; Yun, X. China's innovation system reform and growing industry and science linkages. Res. Policy 2007, 36, 1251-1260. [CrossRef]

20. Xue, L. A historical perspective of China's innovation system reform: A case study. J. Eng. Technol. Manag. 1997, 14, 67-81. [CrossRef]

21. Tylecote, A.; Visintin, F. Corporate Governance, Finance and the Technological Advantage of Nations; Routledge: Abingdon, UK, 2008.

22. Liu, J.; Tylecote, A. Corporate governance and technological capability development: Three case studies in the Chinese auto industry. Ind. Innov. 2009, 16, 525-544. [CrossRef]

23. Yin, R.K. Case Study Research: Design and Methods; SAGE Publications: Thousand oaks, CA, USA, 2009.

24. Bessant, J. Riding the Innovation Wave: Learning to Create Value from Ideas; Emerald Group Publishing: Bingley, UK, 2017.

25. Bessant, J.; Caffyn, S. High-involvement innovation through continuous improvement. Int. J. Technol. Manag. 1997, 14, 7-28. [CrossRef]

26. Bäckström, I.; Bengtsson, L. A mapping study of employee innovation: Proposing a research agenda. Eur. J. Innov. Manag. 2019, 22, 468-492. [CrossRef]

27. Høyrup, S. Employee-Driven Innovation: A New Phenomenon, Concept and Mode of Innovation, in Employee-Driven Innovation; Springer: Berlin/Heidelberg, Germany, 2012; pp. 3-33. 
28. Kesting, P.; Ulhøi, J.P. Employee-driven innovation: Extending the license to foster innovation. Manag. Decis. 2010, 48, 65-84. [CrossRef]

29. Laviolette, E.M.; Redien-Collot, R.; Teglborg, A.-C. Open innovation from the inside: Employee-driven innovation in support of absorptive capacity for inbound open innovation. Int. J. Entrep. Innov. 2016, 17, 228-239. [CrossRef]

30. Chen, Y.S.; Lai, S.-B.; Wen, C.-T. The influence of green innovation performance on corporate advantage in Taiwan. J. Bus. Ethics 2006, 67, 331-339. [CrossRef]

31. Azzone, G.; Bertelè, U. Exploiting green strategies for competitive advantage. Long Range Plan. 1994, 27, 69-81. [CrossRef]

32. Chang, C.-H. The influence of corporate environmental ethics on competitive advantage: The mediation role of green innovation. J. Bus. Ethics 2011, 104, 361-370. [CrossRef]

33. Ceptureanu, S.I.; Ceptureanu, E.G.; Luchian, C.E.; Luchian, I. Community based programs sustainability. A multidimensional analysis of sustainability factors. Sustainability 2018, 10, 870. [CrossRef]

34. Lam, A. Alternative societal models of learning and innovation in the knowledge economy. Int. Soc. Sci. J. 2002, 54, 67-82. [CrossRef]

35. Lam, A.; Lambermont-Ford, J.-P. Knowledge sharing in organisational contexts: A motivation-based perspective. J. Knowl. Manag. 2010, 14, 51-66. [CrossRef]

36. Hoegl, M.; Schulze, A. How to support knowledge creation in new product development: An investigation of knowledge management methods. Eur. Manag. J. 2005, 23, 263-273. [CrossRef]

37. Aoki, K. Transferring Japanese kaizen activities to overseas plants in China. Int. J. Oper. Prod. Manag. 2008, 28, 518-539. [CrossRef]

38. Kajiwara, K. Toyota Way: Shinka Su Ru Saikyo No Keieijutu; Business Sha: Tokyo, Japan, 2002. (In Japanese)

39. Kurz, V.; Hüsig, S.; Dowling, M. What drives different employee types of innovative behaviour? Development and test of an integrative model of employee driven innovation in German firms. Int. J. Entrep. Innov. Manag. 2018, 22, 397-426.

40. Lasrado, F.; Gomiseck, B.; Uzbeck, C. Effectiveness of employee suggestion schemes-from critical success factors to outcomes. Int. J. Qual. Serv. Sci. 2017, 9, 120-136. [CrossRef]

41. Covin, J.G.; Slevin, D.P. A conceptual model of entrepreneurship as firm behavior. Entrep. Theory Pr. 1991, 16, 7-26. [CrossRef]

42. Scott, S.G.; Bruce, R.A. Determinants of innovative behavior: A path model of individual innovation in the workplace. Acad. Manag. J. 1994, 37, 580-607.

43. Lasrado, F.; Arif, M.; Rizvi, A. The determinants for sustainability of an employee suggestion system. Int. J. Qual. Reliab. Manag. 2015, 32, 182-210. [CrossRef]

44. Young, G.J.; Charns, M.P.; Shortell, S.M. Top manager and network effects on the adoption of innovative management practices: A study of TQM in a public hospital system. Strateg. Manag. J. 2001, 22, 935-951. [CrossRef]

45. Tylecote, A.; Cai, J.; Liu, J. Why do mainland Chinese firms succeed in some sectors and fail in others? A critical view of the Chinese system of innovation. Int. J. Learn. Intellect. Cap. 2010, 7, 123-144. [CrossRef]

46. Xiao, Y.; Tylecote, A.; Liu, J. Why not greater catch-up by Chinese firms? The impact of IPR, corporate governance and technology intensity on late-comer strategies. Res. Policy 2013, 42, 749-764.

47. Liu, J.; Tylecote, A. How variations in business systems affect the innovativeness of Chinese firms. In Changing Asian Business Systems: Globalization, Socio-Political Change, and Economic Organization; Whitley, R., Zhang, X., Eds.; Oxford University Press: Oxford, UK, 2016.

48. Lazonick, W.; O'Sullivan, M. Corporate Governance and Sustainable Prosperity; Jerome Levy Economics Institute: New York, NY, USA, 2001.

49. O'Sullivan, M. Contests for Corporate Control: Corporate Governance and Economic Performance in the United State and Germany; Oxford University Press: Oxford, UK, 2000.

50. Cai, J.; Tylecote, A. Corporate governance and technological dynamism of Chinese firms in mobile telecommunications: A quantitative study. Res. Policy 2008, 37, 1790-1811. [CrossRef]

51. Li, Y.; Liu, Y.; Ren, F. Product innovation and process innovation in SOEs: Evidence from the Chinese transition. J. Technol. Transf. 2007, 32, 63-85. [CrossRef]

52. Tylecote, A. Corporate Governance and Technological Development in Chinese Firms, in China's Three Decades of Economic Reforms; Liu, X., Zhang, W., Eds.; Routledge: Abingdon, UK, 2010; pp. 200-210. 
53. Pavitt, K. Technology, Management and Systems of Innovation; Edward Elgar Publishing: Cheltenham, UK, 1999.

54. Boeing, P.; Sandner, P.G. The innovative performance of China's national innovation system. In Proceedings of the DIME-DRUID Academy, Aalborg, Denmark, 20-22 January 2011.

55. Mattlin, M. Chinese strategic state-owned enterprises and ownership control. Biccs Asia Pap. 2009, 4, 1-28.

56. Tylecote, A.; Ramirez, P. Finance, Corporate Governance and the New Techno-Economic Paradigm. Recherches Économiques De Louvain 2008, 74, 583-613. [CrossRef]

57. Lazonick, W. Competitive Advantage on the Shop Floor; Harvard University Press: Cambridge, MA, USA, 1990.

58. Pavitt, K.; Patel, P. The international distribution and determinants of technological activities. Oxf. Rev. Econ. Policy 1988, 4, 35-55. [CrossRef]

59. Cavusgil, S.T.; Calantone, R.J.; Zhao, Y. Tacit knowledge transfer and firm innovation capability. J. Bus. Ind. Mark. 2003, 18, 6-21. [CrossRef]

60. Demirag, I.; Tylecote, A. The effects of organizational culture, structure and market expectations on technological innovation: A hypothesis. Br. J. Manag. 1992, 3, 7-20. [CrossRef]

61. Eisenhardt, K.M. Building theories from case study research. Acad. Manag. Rev. 1989, 14, 532-550. [CrossRef]

62. Seawright, J.; Gerring, J. Case selection techniques in case study research: A menu of qualitative and quantitative options. Political Res. Q. 2008, 61, 294-308. [CrossRef]

63. Huber, G.P.; Power, D.J. Retrospective reports of strategic-level managers: Guidelines for increasing their accuracy. Strateg. Manag. J. 1985, 6, 171-180. [CrossRef]

64. Quinn, P.M. Qualitative Research and Evaluation Methods; Sage Publications Inc.: Thousand Oaks, CA, USA, 2002.

65. Child, J. Managerial and organizational factors associated with company performance part I. J. Manag. Stud. 1974, 11, 175-189. [CrossRef]

66. Dosi, G. The nature of the innovation process. In Technical Change and Economic Theory; Dosi, G., Freeman, C., Nelson, R., Silverberg, G., Soete, L., Eds.; Pinter Publishers: London, UK, 1988; pp. 221-238.

67. Lundvall, B.-A. National Systems of Innovation: Toward a Theory of Innovation and Interactive Learning; Anthem Press: London, UK, 1992; Volume 2.

68. Freeman, C. The economics of technical change. Camb. J. Econ. 1994, 18, 463-514. [CrossRef]

69. Tidd, J.; Bessant, J.; Pavitt, K. Managing Innovation: Integrating Technological, Market and Organizational Change; John Wiley \& Sons Ltd.: Hoboken, NJ, USA, 2005. 